\title{
SPLASH-CUPS, SPRINGBOARDS, AND SINK OR SWIM - PRELIMINARY STUDY OF THE STRATEGIES FOR Vegetative Propagule dispersal in Pygmy Drosera
}

Greg BourKe $\bullet$ Royal Botanic Gardens and Domain Trust • Blue Mountains Botanic Garden Mount Tomah• Bells Line of Road • Mount Tomah 2758 • Australia • greg.bourke@rbgsyd.nsw.gov.au

Keywords: Droseraceae, carnivorous plants, Drosera section Bryastrum, pygmy sundews, dispersal, Australian flora.

Abstract: The Drosera of the subgenus Bryastrum, commonly referred to as pygmy sundews are unique to the genus in that all bar one produce vegetative clonal propagules known as gemmae. These gemmae are thought to be dispersed via a novel adaptation known as a splash-cup, but little is known about its effectiveness or other strategies employed by the plants. In this preliminary study, the splash-cup was tested and its effectiveness measured. The role of the stipules, which form the walls of the splash-cup were also examined along with other features of the plants' architecture. The splash-cup was found to play a critical role in gemmae dispersal while the theory that the stipules perform as spring-loaded catapults was unsupported. Additionally, gemmae were found to either sink or float depending on the taxon. Observational evidence is provided which suggests the structure of a gemma plays a significant role in the success of each taxon in its preferred habitat.

\section{Introduction}

Drosera L. subgenus Ergaleium sect. Bryastrum Planchon is a group of carnivorous plants commonly referred to as pygmy sundews. All bar one, Drosera meristocaulis of South America (Rivadavia et al. 2012) are characterised by their unusual strategy of vegetative propagation through the production of gemmae. With the onset of cooler temperatures, they produce small, hard clusters of modified leaves (gemmae) atop short translucent stalks (Lloyd 1942; Lowrie 1989; Lowrie 2013). Each gemma is attached to its own stalk via just a few cells (Fig. 1) and as it matures, this junction becomes tenuous and is easily broken with the slightest disturbance (pers. obs.). If undisturbed, eventually the gemma's connection is severed by the plant at the cellular level.

Under natural conditions gemmae are dispersed from the parent plant by disturbance (pers. obs.). It is broadly accepted that this process of gemmae distribution is through a novel rain dispersal mechanism known as a splash-cup (Lloyd 1942; Lowrie 1989; Lowrie 2013). This method of propagule dispersal is

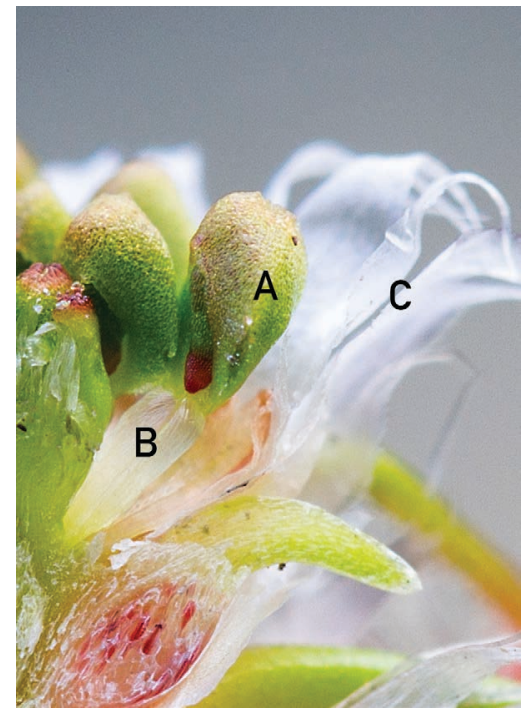

Figure 1: Drosera scorpioides. (A) developing gemma, (B) stalk, (C) stipules forming the wall of the splash-cup. 
well documented from Birds Nest Fungi (Nidulariaceae) and several mosses and liverworts (Brodie 1975). However, a number of plants including Sedum spp., Gentiana spp., Veronica spp. (Nakanishi 2003 ) and at least three other sundews, D. felix, D. kaieteurensis, and D. solaris (Fleischmann et al. 2007) employ this strategy to disperse seeds.

Additional to the splash-cup method, at least one author has suggested the highly developed stipules that form the walls of the splash-cup play a secondary role in gemmae dispersal (Lowrie 1989; Lowrie 2013). Lowrie has hypothesized that the stipules place the developing gemmae under considerable tension (spring force), eventually forcibly dispersing the gemmae when disturbed (Lowrie 1989; Lowrie 2013).

Observations in the field and of cultivated plants by the author suggest gemmae dispersal is affected by a number of factors and is not limited to initial dispersal from the plant. The structure of the gemmae themselves contributes further to dispersal once dislodged from the plant and prior to rooting. Experiments were conducted between 2018 and 2020 under controlled conditions to investigate some of the factors may which may affect gemmae dispersal. These included:

- The splash-cup - dispersal by raindrops

- Springboards - dispersal via stipule spring force

- Sink or swim - secondary dispersal by water

\section{Materials and methods}

The splash-cup - dispersal by raindrops

The splash-cup is a specialised adaptation employed by some organisms to disperse propagules and in pygmy Drosera, a seemingly critical adaptation given the resources used in the process. In some species, at the time gemmae are produced, they may represent as much as $30 \%$ of the biomass of the plant (pers. obs.). In autumn, vegetative propagules grow in the centre of the rosette, surrounded by a number of overlapping stipules. These stipules form the splash-cup and as each gemma matures, it is easily dislodged by disturbance such as rain which, when striking the splash-cup, can carry the gemma some distance from the plant (Fig. 2 ; front cover). It has been suggested this can carry the gemma as far as $2 \mathrm{~m}$ (Lowrie 1989; Lowrie 2013).

As gemmae are produced in the centre of the plant's rosette, the stipules are forced outward. When the first gemmae mature, the stipule cup can vary in shape and size depending on the species, from cupuliform to cyanthiform, with stipule angle commonly between $0^{\circ}$ and $30^{\circ}$ from vertical (pers. obs.). In some species, gemmae production

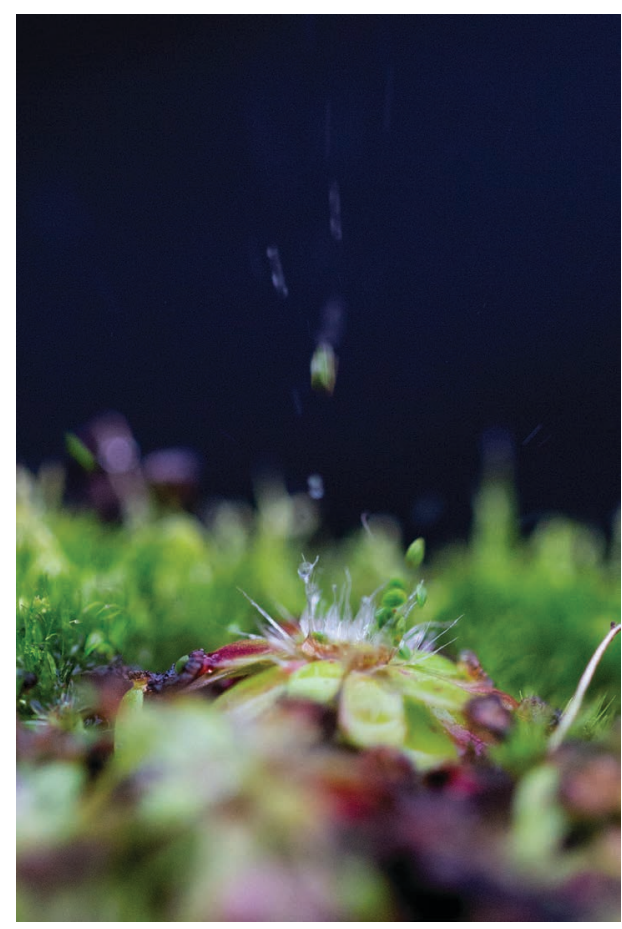

Figure 2: The splash-cup in action. A single water drop distributes gemmae from the centre of a Drosera pulchella. 
continues throughout autumn (e.g., D. pulchella) while others only produce one cluster (e.g., D. miniata) each autumn (A. Fleischmann pers. comm.). As gemmae mature, this angle increases and as the last few gemmae mature, the stipule cup may become crateriform approaching $60^{\circ}$ from vertical. Experiments by Amador et al. (2013) found that the optimal cone angle for a splash-cup is $40^{\circ}$, and all pygmy Drosera observed by the author produce splash-cups of this angle during the production of gemmae. Amador et al. (2013) also found that to achieve the greatest dispersal distance, an off-centre raindrop strike is required. In fact, laboratory experiments demonstrated that an off-centre strike results in an acceleration of the raindrop in a model splash-cup (Amador et al. 2013).

In order to test this, live plants of D. scorpioides and D. pulchella were selected. A single water droplet of $5 \mathrm{~mm}(+/-10 \%)$ diameter was used to simulate a large raindrop. This size is considered to be near the upper limit of falling water drops (Van Boxel 1997). The droplet size was obtained using a 1 litre water vessel fitted with a $3 \mathrm{~mm}$ gate valve, trimmed to achieve a consistent droplet size and droplets weighed to confirm size. The droplet was released from a height of $4 \mathrm{~m}$ above the splash-cup. At this height, approximately $80 \%$ terminal velocity was achieved and a speed of approximately $8 \mathrm{~m} / \mathrm{s}$ (calculated using Van Boxel's rainfall simulator) (Van Boxel 1997).

Each plant was placed in the target area and aligned to achieve an off-centre strike. All gemmae were removed from the rosette centre of the plant and then 10 loose gemmae were placed in the splash-cup. A single water drop was released and distance and distribution of gemmae measured and mapped. This was repeated four times for each of the two Drosera species.

Springboards - dispersal via stipule spring force

To test the theory of stipules dispersing gemmae via spring forces, plants of $D$. scorpioides, D. pycnoblasta, D. pygmaea, and D. pulchella were cultivated in a controlled environment. The species selected represent extremes of growth form for the subgenus, i.e., D. scorpioides con-

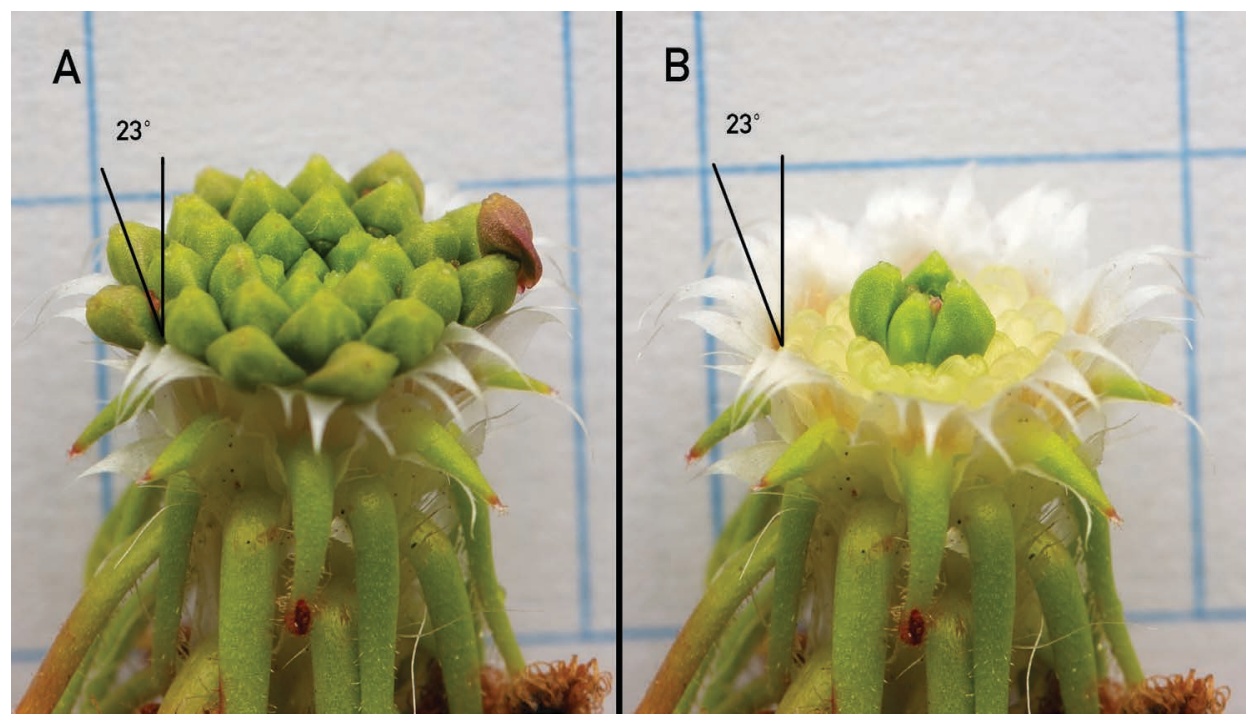

Figure 3: (A) Drosera scorpioides packed with gemmae and (B) with gemmae removed. The angle of the splash-cup wall is shown. 
sidered the tallest, D. pulchella and D. pygmaea being flat rosettes (largest and smallest among the sampled species), and D. pycnoblasta somewhat intermediate in habit. Two groups of plants were monitored. Both groups were allowed to produce gemmae as they would naturally but with no disturbance from overhead watering or any other disturbance forces. At the point where gemmae matured to the stage of naturally disconnecting from the parent plant, one group had its gemmae removed and angle of deflection measured using vernier callipers with one, $D$. scorpioides photographed against a $1 \mathrm{~cm}$ grid (Fig. 3). The second group were left to further mature with gemmae behaviour recorded.

Sink or Swim - secondary dispersal by water

In the wild, pygmy Drosera can be found in a range of habitats from margins of lakes to rocky hillsides in various substrates (pers. obs.; Bourke \& Nunn 2012; Lowrie 2013). Around lake margins, pygmy Drosera can be found in large numbers, often concentrated along the winter high water mark (pers. obs.; Lowrie 2013). This suggests that conditions along the water's edge are ideal from gemmae establishment, that that water may play a role in the distribution of gemmae, or that gemmae that fall outside this zone perish in less than ideal conditions.

Heavy loam soils with laterite form a common substrate for many pygmy Drosera also, and during late autumn when rain is often heavy, water flows across the surface, washing nutrients, debris, and potentially gemmae away. Yet many pygmy Drosera species thrive in these substrates, often on steep gradients, seemingly losing few gemmae to the erosive forces of rain.

To date, there has been little documented as to how and why pygmy Drosera are distributed in such habitats with the implied theory that the plants produce many gemmae relying on luck that some will persist in where and when conditions are favourable. Observations by the author suggests that the gemma shape, surface architecture, and density may play a role in ensuring success.

To test dispersal via water, 30 gemmae of a number of different taxa were dropped from a height of $5 \mathrm{~cm}$ into a $75 \mathrm{ml}$ jar with $50 \mathrm{ml}$ of rain water. The number of floating vs sunken gemmae was recorded. A lid was then placed on the vessel and it was agitated vigorously for 10 seconds. The number of floating vs sunken gemmae was once again recorded. This was tabled against the habitat and soil type from which the plants were sourced.

\section{Results and discussion}

The splash-cup - dispersal by raindrops

The splash-cups were effective in dispersing gemmae but the distances achieved were low. With D. scorpioides, a maximum distance of $73 \mathrm{~cm}$ was achieved with just $20 \%$ exceeding $50 \mathrm{~cm}$ while almost $70 \%$ travelled under $10 \mathrm{~cm}$. Drosera pulchella achieved less impressive results with the furthest gemma at $35 \mathrm{~cm}$ (Fig. 4).

The stiff, erect stems of $D$. scorpioides deflected and sprung back dramatically when struck with a water droplet. The review of video footage suggests that it may actually have a detrimental effect on dispersal as the deflection of the stem consumes energy from striking droplet. This small energy loss may be a trade-off for ensuring the splash-cup is positioned above the often-rocky substrate. In the wild, plants often occur in dense populations, providing support for each other which could remove some of this deflection when struck.

The angle of the splash-cup walls changes over time and between species (pers. obs.). Further experiments are required for a broader range of species and at different stages of development in order to gain a better understanding of the effectiveness and of the splash-cup. 


\section{Drosera scorpioides}

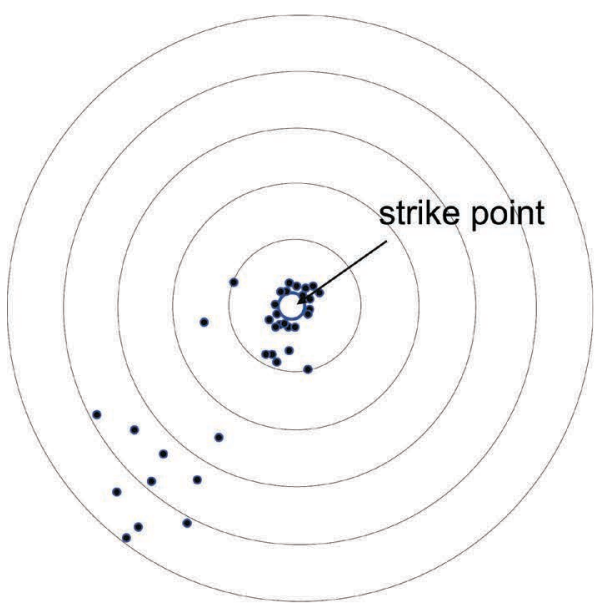

\section{Drosera pulchella}

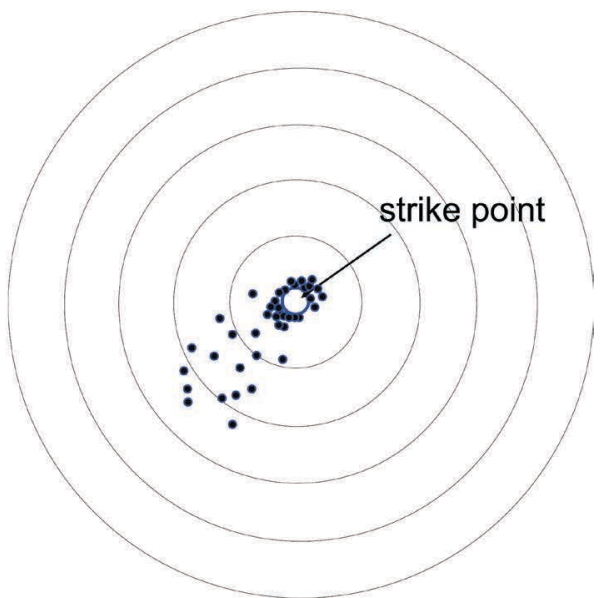

Figure 4: Location and orientation of dispersed gemmae following an off-centre water droplet strike. The centre circle represents the splash-cup with thin concentric circles representing $15 \mathrm{~cm}$ increments.

Springboards - dispersal via stipule spring force

According to Lowrie (2013), as gemmae mature, they place the stipules which form the walls of the splash-cup under tension and any disturbance such as that from a raindrop, will cause the cluster of gemmae to explode, being forcibly evacuated from the plant. Unfortunately, the process outlined by Lowrie was not able to be replicated in this study. With $D$. pulchella, as gemmae matured and were severed by the plant, they were simply pushed upward by the developing gemmae below, bound by the walls of the splash-cup (Fig. 5 Left). In D. pycnoblasta and D. scorpioides, the mature gemmae simply commenced leaf and root development whilst more or less remaining in position within the splash-cup (Fig. 5 Right).

In the second group of plants, removal of gemmae from a full splash cup resulted in no deflection of the stipules (Fig. 3). It appears that the petiole bases from which the gemmae develop are what force the stipules apart. However, gemmae placed against the wall of stipules could be dispersed some distance by pushing the stipule outwards with tweezers and then releasing the applied spring tension.

Further investigation is required to determine whether Lowrie's observation is a rare occurrence or whether it occurs in some, but not all taxa.

Sink or swim - secondary dispersal by water

The results of the 21 taxa tested are provided in table 1. Of the taxa tested, those associated with laterite/gravel soils on sloping ground, $62 \%$ of gemmae sunk when dropped into water. This figure rose to over $90 \%$ when agitated. As for species associated with swamps and lakes, just $9 \%$ sunk when dropped into water while $31 \%$ sunk when agitated.

Four taxa were excluded from these calculations. Drosera echinoblastus and D. mannii inhabit the margins of streams as well as heath and woodlands, while $D$. helodes and D. micrantha inhabit fairly open heath in flat, low lying areas. It is the opinion of the author that whether the gemmae of these taxa float or sink probably doesn't play a significant role in their success but further investigation may be useful. 

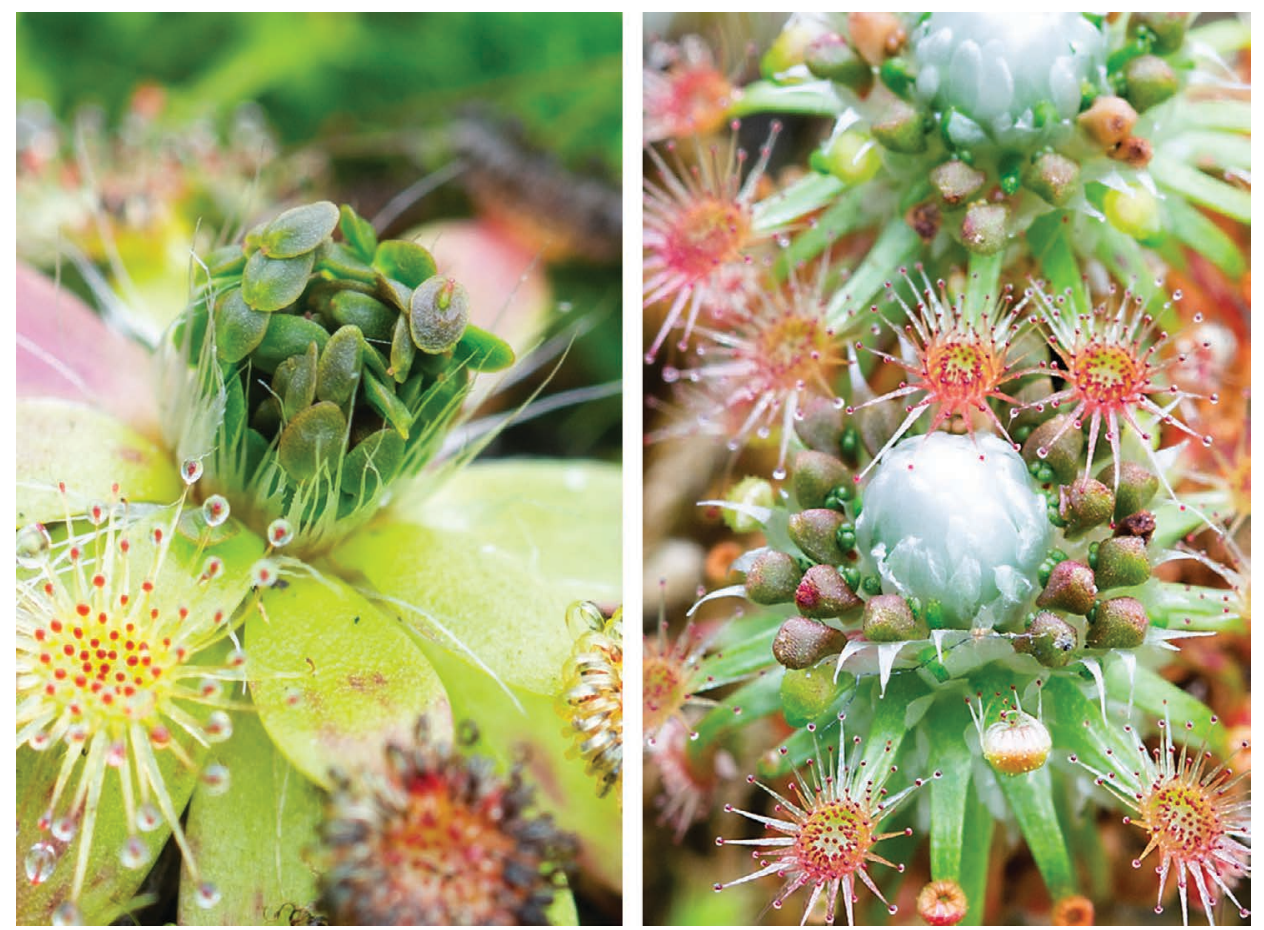

Figure 5: Left: Drosera pulchella left undisturbed with gemmae piling up. Right: Drosera pycnoblasta left undisturbed with sprouting gemmae.

Interestingly, the two D. scorpioides samples from contrasting habitats provided clear and opposing results with $100 \%$ of those originating from laterite soils sinking while $0 \%$ of those originating from swampy habitat sunk. This is consistent with other taxa from comparable habitat and soil types. As the material tested originated from cultivated plants, it is not possible that this is as a result of environmental factors and therefore must represent genetic variation. Further sampling is required of these taxa to better understand these taxa.

\section{Conclusions}

This preliminary study provides the first data from tests conducted in a controlled environment for pygmy Drosera gemmae dispersal. The splash-cup is an effective adaptation for distributing gemmae but the data did not support that found in some literature. Testing of a broader range of taxa is required to confirm just how successful the splash-cup is for gemmae dispersal in pygmy Drosera. The primary role of the stipules was found to be in the production of the wall of the splash-cup and the claim that spring tension plays a role in distribution of gemmae in an explosive event was unsupported. Stipules were found to provide a means of gemmae dispersal when disturbed and their role in gemmae dispersal requires further investigation.

Whilst the data provided good insight into the theory of secondary distribution of gemmae, the results of different D. pygmaea and D. scorpioides samples suggest broader sampling of a range of taxa is required to better understand this strategy and perhaps provide insight into the evolutionary adaptations developed by isolated populations. 


\begin{tabular}{|c|c|c|c|c|}
\hline Taxon & $\begin{array}{c}\text { No. sink } \\
\text { when } \\
\text { dropped }\end{array}$ & $\begin{array}{c}\text { No. sink } \\
\text { after } \\
\text { agitation }\end{array}$ & Habitat & Soil type \\
\hline D. closterostigma & 21 & 28 & $\begin{array}{l}\text { winter wet depressions } \\
\text { and swamps }\end{array}$ & pale sand \\
\hline D. echinoblastus & 27 & 30 & $\begin{array}{l}\text { margins of seasonally } \\
\text { wet streams }\end{array}$ & pale sand \\
\hline D. enodes & 0 & 0 & winter wet depression & peat based \\
\hline D. gibsonii & 30 & 30 & sloping hillsides in heath & laterite/gravel \\
\hline D. helodes & 15 & 29 & low lying areas & pale sand/laterite \\
\hline D. lasiantha & 26 & 30 & $\begin{array}{l}\text { sloping hillsides in heath } \\
\text { and open woodland }\end{array}$ & laterite \\
\hline D. leucostigma & 0 & 10 & $\begin{array}{l}\text { winter wet depressions } \\
\text { and swamps }\end{array}$ & pale sand and peat \\
\hline D. mannii & 0 & 15 & $\begin{array}{l}\text { watersheds and creek } \\
\text { margins }\end{array}$ & peat or laterite \\
\hline D. micrantha & 28 & 30 & flat open heath & pale sand \\
\hline D. nitidula & 0 & 18 & $\begin{array}{l}\text { seasonally flooded } \\
\text { depressions and swamps }\end{array}$ & yellow sand with clay \\
\hline D. occidentalis & 0 & 1 & margins of swamps & peat \\
\hline D. patens & 0 & 0 & $\begin{array}{l}\text { margins of swamps and } \\
\text { lakes }\end{array}$ & pale sand \\
\hline D. platystigma & 0 & 21 & $\begin{array}{l}\text { flat to gently sloping } \\
\text { hillsides in woodland }\end{array}$ & laterite \\
\hline $\begin{array}{l}\text { D. pulchella }(\text { Scott } \\
\text { River) }\end{array}$ & 0 & 10 & margins of swamps & pale sand/peat \\
\hline $\begin{array}{l}\text { D. pulchella } \\
\text { (Mt. Cooke) } \\
\end{array}$ & 0 & 10 & $\begin{array}{l}\text { seasonally inundated } \\
\text { swamps }\end{array}$ & pale sand \\
\hline $\begin{array}{l}\text { D. pygmaea } \\
\text { (Cox Scrub S.A.) }\end{array}$ & 0 & 6 & margins of swamps & black sand/peat \\
\hline $\begin{array}{l}\text { D. pygmaea } \\
\text { (Kai Iwi Lake N.Z.) }\end{array}$ & 10 & 20 & margin of lake & pale sand/peat \\
\hline $\begin{array}{l}\text { D. scorpioides } \\
\text { (Albany) }\end{array}$ & 30 & 30 & $\begin{array}{l}\text { sloping hillsides in heath } \\
\text { and open woodland }\end{array}$ & laterite \\
\hline $\begin{array}{l}\text { D. scorpioides } \\
\text { (Marbleup) }\end{array}$ & 0 & 0 & $\begin{array}{l}\text { seepage margin of } \\
\text { swamp }\end{array}$ & pale sand/peat \\
\hline D. stelliflora & 0 & 26 & $\begin{array}{l}\text { flat to gently sloping } \\
\text { hillsides in woodland }\end{array}$ & laterite \\
\hline D. verrucata & 26 & 26 & sloping hillsides in heath & laterite \\
\hline
\end{tabular}




\section{References}

Amador, G.J., Yamada, Y., McCurley, M., and Hu, D.L. 2013. Splash-cup plants accelerate raindrops to disperse seeds. J. Royal Soc. Interface 10: 20120880. http://dx.doi.org/10.1098/rsif.2012.0880 Bourke, G., and Nunn, R. 2012. Australian Carnivorous Plants. Redfern Natural History Productions, Poole.

Brodie, H.J. 1975. The Bird's Nest Fungi. University of Toronto Press.

Fleischmann, A., Wistuba, A., and McPherson, S. 2007. Drosera solaris (Droseraceae), a new sundew from the Guayana Highlands. Willdenowia 37: 551-555.

Lowrie, A. 1989. Carnivorous Plants of Australia. Volume 1. University of Western Australia Press, Nedlands.

Lowrie, A. 2013. Carnivorous Plants of Australia Magnum Opus. 3 Volumes. Redfern Natural History Productions, Poole.

Lloyd, F.E. 1942. The Carnivorous Plants. Chronica Botanica Company, Waltham.

Nakanishi, H. 2003. Splash seed dispersal by raindrops. Ecological Research 17: 663-671.

Rivadavia, F., de Miranda, V.F.O., Hoogenstrijd, G., Pinheiro, F., Heubl, G., and Fleischmann, A. 2012. Is Drosera meristocaulis a pygmy sundew? Evidence of a long-distance dispersal between Western Australia and northern South America. Annals of Botany 110(1): 11-21.

Van Boxel, J.H. 1997. Numerical model for the fall speed of raindrops in a rainfall simulator. Workshop on Wind and Water Erosion. Ghent Belgium. https://web.archive.org/web/20130731002444/ http://staff.science.uva.nl/ jboxel/Publications/PDFs/Gent_98.pdf

\section{Online Guide to the Pygmy Drosera}

https://www.carnivorousplants.org/cp/taxonomy/pygmyDrosera

The ICPS public education website has a new online guide to the pygmy Drosera located in the About CPs/Taxonomy section. The guide is intended for use in identifying plants in cultivation as well as in the field. The pages adapt to screen size and work well with personal computers, tablets, and phones.

The guide includes short introductions to all 54 species and 6 taxonomically named hybrids. There are currently 332 images in the guide. The images were provided by Richard Nunn, Thilo Krueger, Manfred Meisterl, Steve Fretwell, Stewart McPherson, and John Brittnacher.

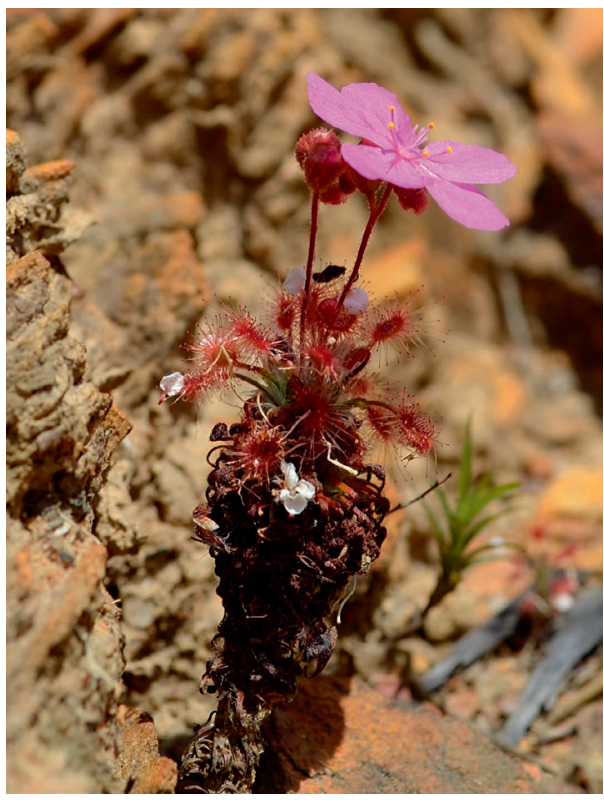

Drosera gibsonii. Photo by Thilo Krueger. 


\section{CARNIVOROUS PLANT NEWSLETTER}

Journal of the International Carnivorous Plant Society

Volume 50, No. 2

June 2021 


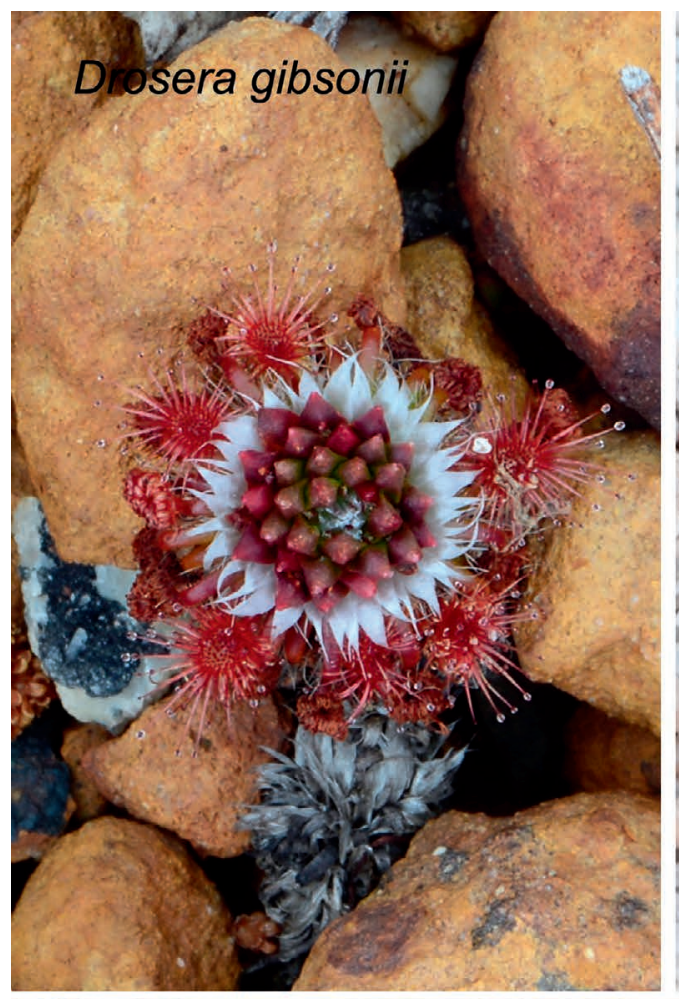

Drosera micrinthat menos of

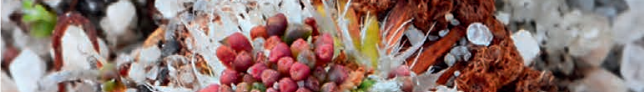
som in. a. $x$ -

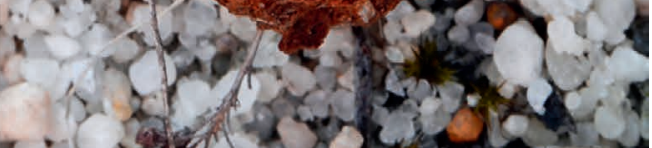

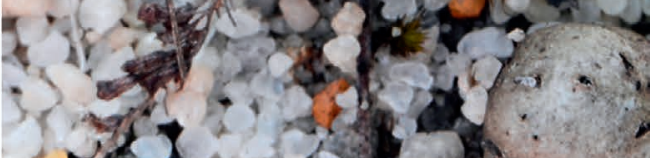
Drosera leucostigma Drosera leucostigma
a

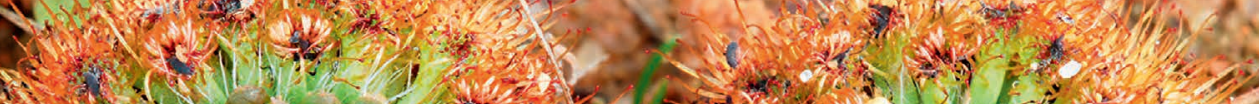

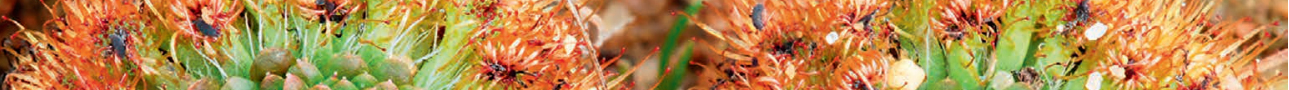

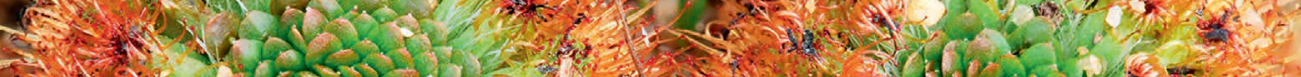

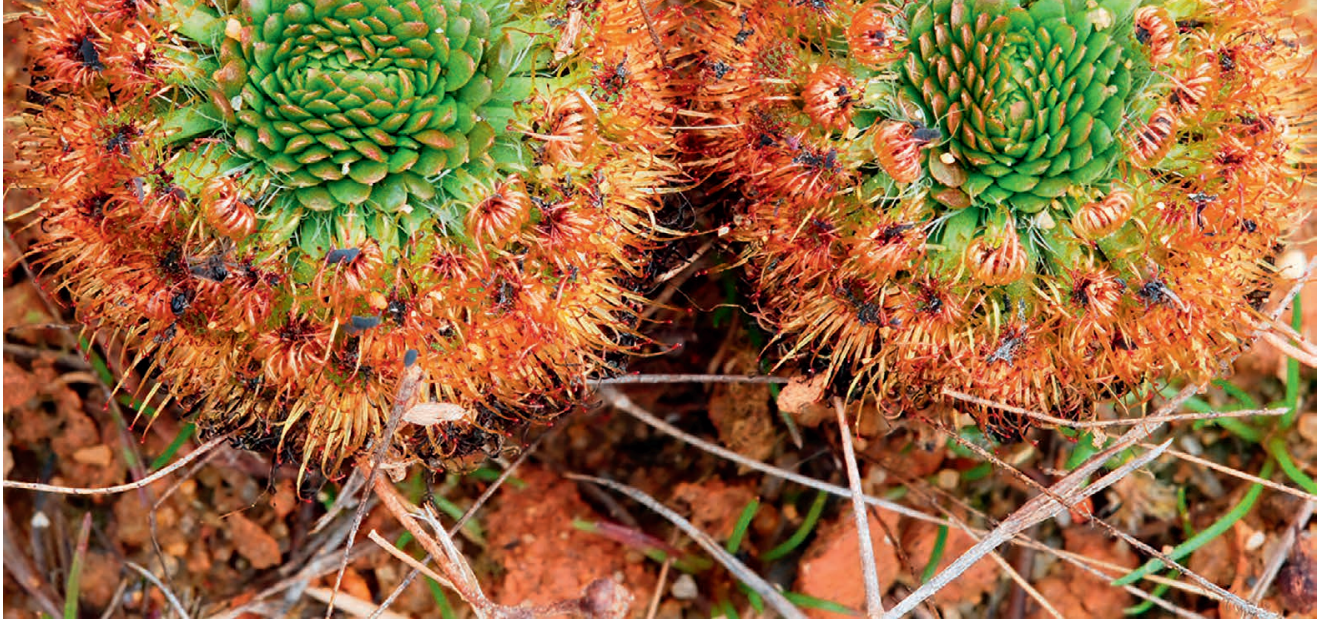




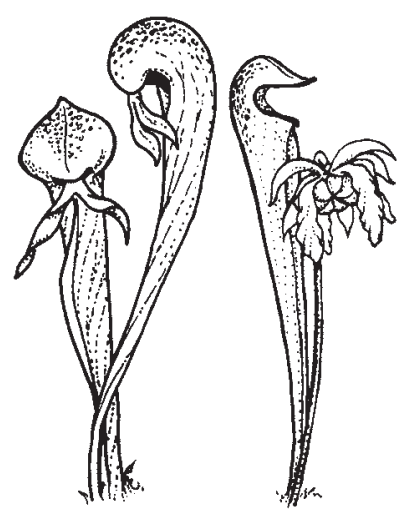

\section{CARNIVOROUS \\ PLANT \\ NEWSLETTER}

Journal of the International

Carnivorous Plant Society

www.carnivorousplants.org

\section{Volume 50, Number 2 June 2021}

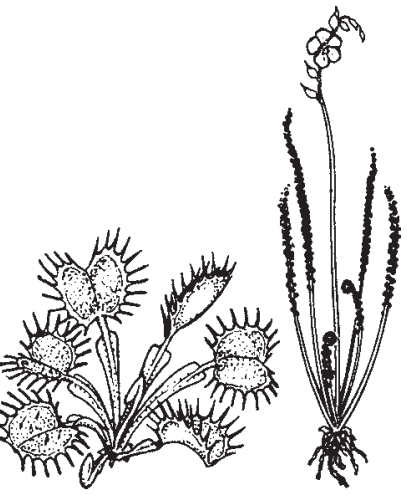

Front Cover: The splash-cup in action. A single water drop distributes gemmae from the center of a Drosera pulchella. Photo by Greg Bourke. Article on page 52.

\section{Back Cover: Drosera gibsonii at Buff Knoll, D. micrantha at Muchea, and D. leucostigma at Regans Ford, all in Western Australia. Photos by Richard Nunn. Article on page 52.}

Carnivorous Plant Newsletter is dedicated to spreading knowledge and news related to carnivorous plants. Reader contributions are essential for this mission to be successful. Do not hesitate to contact the editors with information about your plants, conservation projects, field trips, or noteworthy events. Advertisers should contact the editors. Views expressed in this publication are those of the authors, not the editorial staff.

All correspondence regarding dues, address changes and missing issues should be sent to the Membership Coordinator at the ICPS. Do not send such correspondence to the editors. Checks for subscriptions should be made to the International Carnivorous Plant Society in US funds. Dues, including a subscription, are \$35 per year.

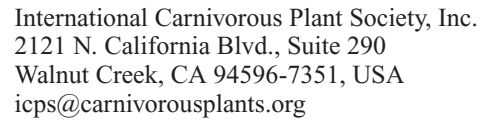

President

Vice President

Secretary

Treasurer

Board Member

Board Member

Board Member

Board Member

Board Member

Membership Coordinator

Webmaster

Media Coordinator

Seed Bank Manager

Facebook Manager

CPN Editors

Managing Editor

Editor

Editor

Editor
Richard Nunn, richardnunn@carnivorousplants.org

John Brittnacher, john@carnivorousplants.org

Cindy Slezak, cindy@carnivorousplants.org

Daniela Ribbecke, daniela@carnivorousplants.org

Kenny Coogan, Education Director, kenny@carnivorousplants.org

Brent Jones, brent@carnivorousplants.org

Jan Schlauer, Cultivar Registrar, jan@carnivorousplants.org

Carson Trexler, Conservation Director, carson@carnivorousplants.org

BobZiemer, bob@carnivorousplants.org

Cindy Slezak, cindy@carnivorousplants.org

John Brittnacher, john@carnivorousplants.org

Chad Williams, chad@carnivorousplants.org

Joe Griffin, joe@carnivorousplants.org

Marcel van den Broek, marcel@carnivorousplants.org

Date of effective publication of the March 2021 issue of Carnivorous Plant Newsletter: February 16, 2021.

The ICPS is the International Cultivar Registration Authority (ICRA) for the names of cultivated carnivorous plants according to the International Code of Nomenclature for Cultivated Plants. Send relevant correspondence to the ICPS, Inc.

Carnivorous Plant Newsletter is published quarterly in March, June, September, and December by the ICPS, Inc., 2121 N. California Blvd., Suite 290, Walnut Creek, CA 94596, USA. Periodicals postage paid at Walnut Creek, CA and additional mailing offices. Postmaster: Send address changes to ICPS, Inc., 2121 N. California Blvd., Suite 290, Walnut Creek, CA 94596, USA. Printed by Allen Press, Inc., 810 E. 10th Street, Lawrence, KS 66044. Logo and masthead art: Paul Milauskas. (C) 2021 International Carnivorous Plant Society. All rights reserved. ISSN \#0190-9215 